\title{
金属鉄粒子を分散させた水べース磁性流体の作製
}

\author{
藤 田豊 久, Balachandran Jeyadevan, 真宮三男
}

秋田大学鉱山学部, 干010 秋田市手形学園町1-1.

\section{Preparation of Water Based Magnetic Fluid Dispersing Colloidal Metallic Iron}

\author{
Toyohisa Fujita, Balachandran Jeyadevan and Mitsuo Mamiya
}

Mining College, Akita University, 1-1 Tegata Gakuen-cho Akita 010.

Received November 26, 1990

\begin{abstract}
The $\alpha$-Fe particles were prepared by reducing the ferrous ion in sodium borohydride aqueous solution in the presence of surfactant, sodium oleate. The particles prepared were dispersed stably in tetramethylammonium (TMA) hydroxide aqueous solution with sodium dodecylbenzenesulfonate (SDBS). The stability of the suspension depended on the SDBS and TMA hydroxide concentration. The effect of iron concentration on the viscosity of suspension was studied and the apparent adsorbed layer thickness was evaluated to be about $10 \mathrm{~nm}$. The suspension when exposed to a magnetic field distribution was separated into two phases. The sunk black phase retained the flowability and did not coagulate under the employed magnetic field distribution, this being considered as a stable magnetic fluid. For example, a magnetic fluid with saturation magnetization of $0.036 \mathrm{~T}$ was prepared. Optical microscopic observation of $2 \mu \mathrm{m}$ thin magnetic fluid film under magnetic field showed the existence of iron particle clusters. The viscosity of the magnetic fluid measured in a cylindrical viscometer showed about two fold increase in viscosity under a magnetic field of $280 \mathrm{kA} / \mathrm{m}$.
\end{abstract}

\section{I 緒言}

磁化の高い金属鉄粒子等を分散させた館和磁化の高い 磁性流体，さらに特殊な機能をむつ磁性流体の開発が各 種応用面から望まれている、 $\mathrm{Fe}(\mathrm{CO})_{5}$ と $\mathrm{N}_{2}$ ガスのプラ ズマCVD 反応法あるいは気相液相反応法で作製した窒 化鉄粒子を油中に分散させた油べースの磁性流体の製造 は，近年報告されている1゙が，氷中に金属鉄粒子を分散 させた水ベース磁性流体の製造はまだ報告されていな い.

一方, $10 \mathrm{~nm}$ 程度のマグネタイト $\left(\mathrm{Fe}_{3} \mathrm{O}_{4}\right)$ 粒子を水中 に分散させ，水べース磁性流体を作製する方法は大さく 2つに分けられる.一つは，下飯坂らの方法2で，マグ
ネタイト表面の第一層目にオンイン酸イオンを吸着さ せ，第二層目にドデシルベンゼンスルホン酸 (DBS) イ オン等の界面活性昘を吸着させて水《分散させる方法で ある。む5一つは Massart ら 3 の方法で，界面活性剤を 使用せず，マグネタイト表面をテトラメチルアンモニウ 么 (TMA) イオンを含む水溶液中で正火荷電させ，分散 させる方法である。

前報4)では，界面活性剤を含んだ水溶液中で水素化木 ウ素ナトリウムによる第一鉄イオンの還元を試み, 金属 鉄の粒径が小となるよらに制御することを報告した．本 報では，この調製した金属鉄粒子を界面活性昘と TMA イオンの厚い層で被覆することにより，水中に安定に分 散させて磁性流体化することを検討した。 


\section{II 粒子間の相互作用}

Rosensweig は界面活性鼡で被覆した磁性粒子の液体 中での相互作用力によるエネルギーとして次の 3 式を示 した5,6). 粒子間の磁気力によるエネルギー $\mathrm{V}_{\mathrm{m}}$ は，

$$
\mathrm{V}_{\mathrm{m}}=-\frac{8}{9} \frac{\pi \mathrm{M}^{2} \mathrm{r}^{3}}{\mu_{\mathrm{o}}(\mathrm{h}+2)^{3}}
$$

ここに M は粒子の磁化, $\mu_{\mathrm{o}}$ は真空の透磁率 $\left(4 \pi \times 10^{-7}\right.$ $\mathrm{H} / \mathrm{m}), \mathrm{r}$ は粒子半径, $\mathrm{h}$ は 2 つの粒子の中心間距離を $\mathrm{R}$ とすると $\mathrm{h}=(\mathrm{R}-2 \mathrm{r}) / \mathrm{r}$ である. 界面活性剤吸着層によ って生しる立体障害効果によるエネルギー $\mathrm{V}_{\mathrm{r}}$ は

$$
\mathrm{V}_{\mathrm{r}}=2 \pi \mathrm{r}^{2} \mathrm{NkT}\left\{2-\frac{\mathrm{h}+2}{\delta / \mathrm{r}} \ln \left(\frac{1+\delta / \mathrm{r}}{1+\mathrm{h} / 2}\right)-\frac{\mathrm{h}}{\delta / \mathrm{r}}\right\}
$$

ここにN は粒子表面の界面活性剤の吸着密度 $\left(\mathrm{N}=3 \times 10^{18}\right.$ 分子 $/ \mathrm{m}^{2}$ と仮定 $), \delta$ は吸着層の厚さ, $\mathrm{k}$ はボ ルッマン定数, $\mathrm{T}$ は絶対温度である. 粒子間のファン・ デル・ワールスカによるェネルギー $\mathrm{V}_{\mathrm{a}}$ は，

$$
\mathrm{V}_{\mathrm{a}}=-\frac{\mathrm{A}}{6}\left\{\frac{2}{\mathrm{~h}(\mathrm{~h}+4)}+\frac{2}{(\mathrm{~h}+2)^{2}}+\ln \frac{\mathrm{h}(\mathrm{h}+4)}{(\mathrm{h}+2)^{2}}\right\}
$$

ここに A は Hamaker 定数 $\left(10^{-19} \mathrm{~J}\right.$ と仮定)である. 調製 した金属鉄粒子の飽和磁化を約 $1.2 \mathrm{~T}$ (金属鉄の館和磁 化は約 $2.1 \mathrm{~T}$ であるが，本実験で調製した金属鉄粒子は これよりる低くTMA イオンが存在する水溶液中で 1.2 $\mathrm{T}$ と仮定）とし，粒子半径怙よび界面活性剂の吸着層の 厚さを変兄た場合の $\mathrm{V}_{\mathrm{m}}+\mathrm{V}_{\mathrm{r}}+\mathrm{V}_{\mathrm{a}}$ 曲線を Fig. 1 亿示す. 全ポテンシャルメネルギーより常に正の大きいポテンン ヤルェネルギー障壁をるつ粒子が安定な分散状態を得る ことが可能である。みかけの界面活性剤の吸着層の厚さ がオレイン酸イオンのみの被覆で $3 \mathrm{~nm}$ であれば, 10 $\mathrm{nm}$ の粒子は第 2 極小が生じ, 安定な分散は得られない。 そこで，吸着層の厚さを $5 \mathrm{~nm}$ と増すと $10 \mathrm{~nm}$ の粒径す では分散が可能でさらに，吸着層の厚さが $10 \mathrm{~nm}$ にな ると，18 nm の粒径まで分散が可能となる，それ以上の 粒径では深い第 2 極小の谷が生じる.オレイン酸イオン

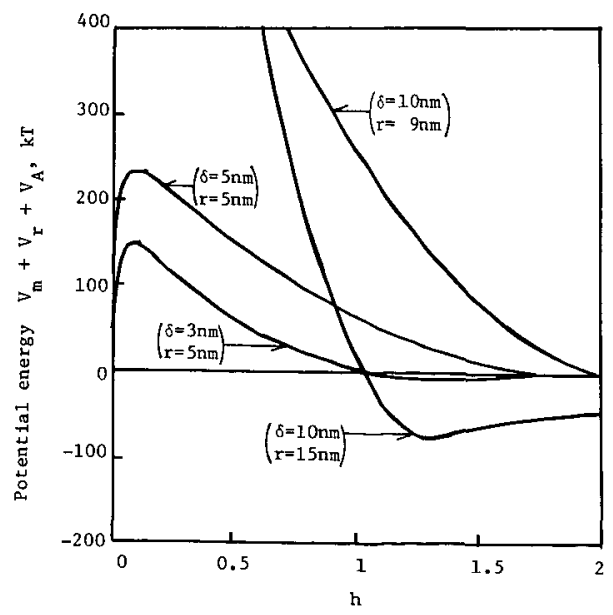

Fig. 1 Potential energy versus surface-to-surface separation of sterically protected colloidal particles.

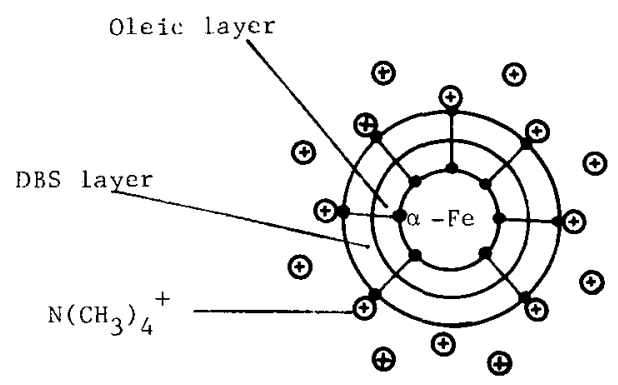

Fig. 2 Schematic representation of metallic iron in water.

のみで完全被覆された場合の純鉄粒子を用いて磁性流体 の作製が可能な粒径は 2〜 $6 \mathrm{~nm}^{4)}$ といわれているが，こ れに比し飽和磁化が $1.2 \mathrm{~T}$ の粒子では，見かけの吸着層 の厚さを增すと，さらに粒径の大きな粒子の分散が可能 であると考えられる。

そこで，本実験では Fig. 2 の概念図のよ5に，金属鉄 粒子を被覆しているオレイン酸イオン層の外側に DBS イオンを被覆させ，さらにその外側をTMAイオン雾囲 気とし，金属鉄粒子を被覆する久かけの吸着層を增大さ せることにより粒子間の磁気的な吸引力に打ち勝つよう に粒子の分散を試みた.

\section{III 実 験 方 法}

前報2)で報告したよらに還元刘である水素化ホウ素ナ トリウムの水溶液中に才レイン酸ナトリウム $3 \times 10^{-3}$ $\mathrm{mol} / 1$ を溶解させて拈き，これ飞硫酸第一鉄を $8.3 \times 10^{-3}$ $\mathrm{mol} / 1$ 添加して金属鉄粒子を調製した。この水分を含む 凝集した金属鉄粒子を，各種濃度のドデシルベンゼンス ルホン酸ナトリウム (SDBS) 拉よび TMA hydroxide 水 溶液中に入れ超音波で分散させることにより，懸濁夜を 得た。この懸濁液を円筒容器に満たし，Fig. 3 に示す磁 界分布中に静置して金属鉄粒子の沈降状態を検討した。 永久磁石表面での磁界強度は約 $250 \mathrm{kA} / \mathrm{m}$ ，表面から 5 $\mathrm{mm}$ 離れた位置に括怙る磁界公配は約 $1 \times 10^{4} \mathrm{~A} / \mathrm{m}^{2}$ であ る。

金属鉄粒子を分散した水べース磁性流体の粘度は，島 津レオメータ RM-1 型の二重円筒型 (内径 $27 \mathrm{~mm}$, 外径 $30 \mathrm{~mm}$ ) で測定し，むた磁界を作用させた場合の粘度は， この円筒の両側に垂直に $280 \mathrm{kA} / \mathrm{m}$ の磁界を作用させて 測定した。

また，作製した水ベース磁性流体を薄いガラスで挟み $2 \mu \mathrm{m}$ 薄膜として光学顕销鏡にて, 磁界を作用させた場 合と，作用させない場合の状態を観察した.

\section{$N$ 実験結果および考察}

Fig. 4 は金属鉄粒子を安定に分散させた懸濁液を得る ために必要な TMA hydroxide と SDBS の濃度との関係 を示したものである.本実験ではFig. 3 に示した磁界分 


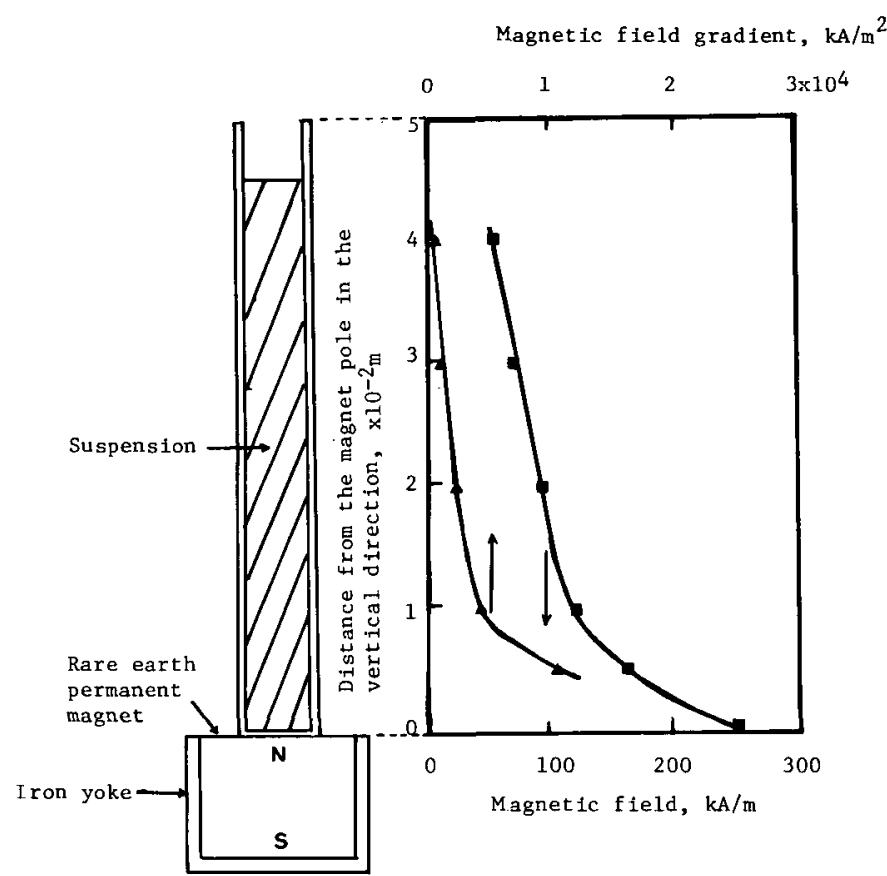

Fig. 3 The distribution of intensity of magnetic field and magnetic field gradient in the cylinder used to observe the stability of suspension on the permanent magnet.

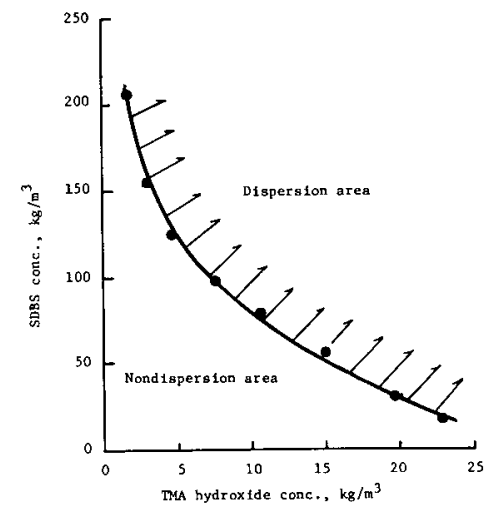

Fig. 4 Relation between TMA hydroxide concentration and SDBS concentration to prepare stable suspension of metallic iron particles.

$\left(\mathrm{pH} 14-14.5, \mathrm{Fe}\right.$ conc. $\left.10 \mathrm{~kg} / \mathrm{m}^{3}\right)$

布を示す円筒中に 3 分間懸濁液を放置しても沈降を生じ ない場合を分散の限界として示してある。 TMA hydroxide 濃度が増加するにつれて分散に必要な SDBS 濃度は 減少し，またSDBS 濃度が増加するにつれて分散に必要 な TMA hydroxide 濃度は減少した，金属鉄粒子を含ま ないTMA hydroxide を含有する水溶液中でその濃度が $4.5 \mathrm{~kg} / \mathrm{m}^{3}$ の中に, SDBS を添加していきその導電率を 測定したところ，SDBS 濃度が $10 \mathrm{~kg} / \mathrm{m}^{3}$ までは尊電率は 増加し，それ以上の濃度では低下した。 DBS イオンは SDBS が $10 \mathrm{~kg} / \mathrm{m}^{3}$ 以上の濃度で一部を除いて TMA オオ

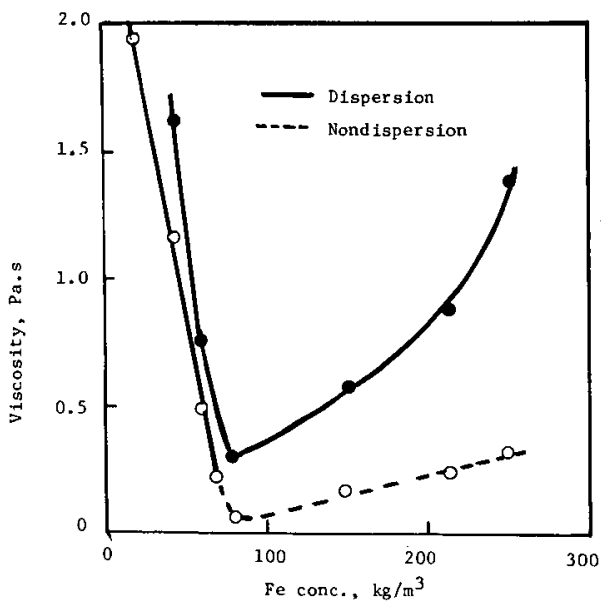

Fig. 5 Effect of iron concentration on viscosity of the suspension of metallic iron particles.

(TMA hydroxide conc $4.5 \mathrm{~kg} / \mathrm{m}^{3}$

(SDBS conc. $140 \mathrm{~kg} / \mathrm{m}^{3}, 160 \mathrm{~kg} / \mathrm{m}^{3}$ )

\section{ンと化合物を形成していると考えられる。}

Fig. 5 は, TMA hydroxide 濃度 $4.5 \mathrm{~kg} / \mathrm{m}^{3}$, SDBS 濃度 140 あるいは $160 \mathrm{~kg} / \mathrm{m}^{3}$ の水溶液中に種々の濃度の金属 鉄粒子を㲘濁させて作製した懸濁液の粘度を示したるの である.金属鉄粒子を添加していくと鉄濃度が $80 \mathrm{~kg} / \mathrm{m}^{3}$ となるまで粘度は減少し，それ以上の鉄濃度になると粘 度は再び増加した．鉄濃度が $80 \mathrm{~kg} / \mathrm{m}^{3}$ むでの添加では， 金属鉄粒子を添加するにしたがい，液体中の DBS イオ 


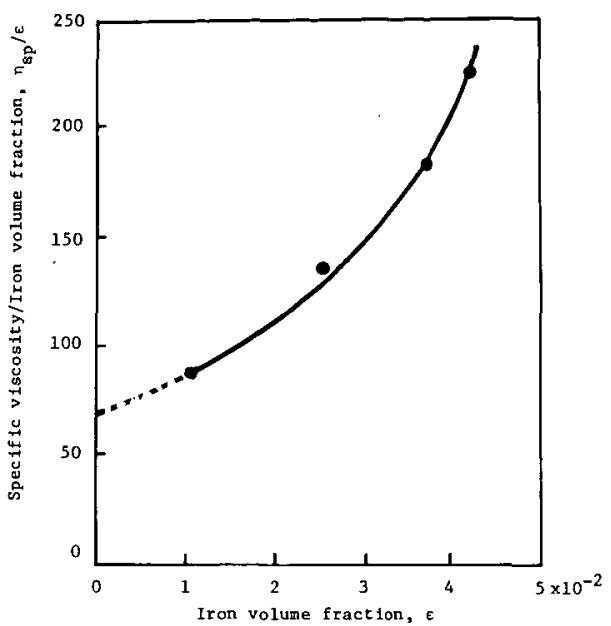

Fig. 6 Plot of $\eta_{\mathrm{sp}} / \varepsilon$ versus iron volume fraction $\varepsilon$.

ンが金属鉄粒子表面に集合して吸着するために粘度が低 下したと推定される．それ以上の粘度の増加は金属鉄粒 子の濃度が増加したことによる粒子体積の増加によると 考忩られる。米た，SDBS 濃度が $140 \mathrm{~kg} / \mathrm{m}^{3}$ の場合には 鉄濃度が $80 \mathrm{~kg} / \mathrm{m}^{3}$ を越えると Fig. 3 の装置では沈降を 生じたが，一方, SDBS 濃度を $160 \mathrm{~kg} / \mathrm{m}^{3}$ とした場合に は, Fig. 5 そ示す鉄濃度の範囲では安定に分散を保った。

Fig. 6 は, $80 \mathrm{~kg} / \mathrm{m}^{3}$ 以上の鉄濃度の体積分率と比粘度 を体積分率で除した値との関係を示したものである。た だし，水素化ホウ素ナトリウムで還元して得た金属鉄粒 子の密度はホウ素や酸素の含有のために䄪 $6000 \mathrm{~kg} / \mathrm{m}^{37)}$ と報告されて括り，本研究でるこの密度を使用した．金 属鉄粒子を被覆するみか子吸着層の厚さ $\delta$ は, 粒子半 径を $\mathrm{r}$ として次式で与兄られる5

$$
\lim _{\epsilon \rightarrow 0}\left(\eta_{\mathrm{sp}} / \varepsilon\right)=2.5(1+\delta / \mathrm{r})^{3}
$$

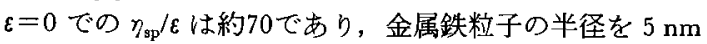
とすると, 金属鉄粒子表面の及かけの吸着層の厚さは約 $10 \mathrm{~nm}$ と計算される。よって, Fig. 1 で示したポテンシ ヤル曲線からも調製した金属鉄粒子の分散が可能である と推定された．従来の水ベース磁性流体中でマグネタイ 卜粒子表面を被覆する吸着層の厚さが $5 \mathrm{~nm}$ であること と比較して，金属鉄粒子への吸着層の厚さは 2 倍と考え られる．同じ粒子の体積分率ならば，本実験で作製した 緊濁液の粘度は增大すると考えられるが，実際にマグネ タイトを分散させた磁性流体の粘度 ${ }^{8)}$ 上りも金属鉄粒子 を分散させた場合の粘度は 1 析上昇した。

Fig. 7 は $80 \mathrm{~kg} / \mathrm{m}^{3}$ の金属鉄粒子を分散させた懸濁液を Fig. 3 に示寸磁界中に長時間静置させた場合の沈降界面 高さを示したものである。ここで使用した懸濁液は Fig. 4 で分散領域にあるものである.充分時問が経過すると， 上部は透明な液体となり，彩濁液は二層分離を生じた。 層分離については Bacri らがフェライトを用いたイオン

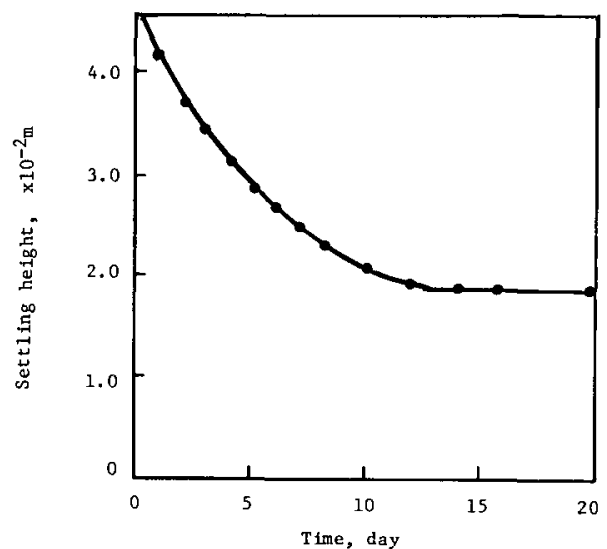

Fig. 7 Settling rate of the iron particles in the suspension of 80 $\mathrm{kg} / \mathrm{m}^{3}$ metallic iron particles when exposed to the magnetic field distribution as shown in Fig. 3.

性磁性流体について報告9〕している．10日以上経過する と二層分離した沈降界面の高さは注とんど変化せず，一 定となった. 下部から $10 \mathrm{~mm}$ の部分では Fig. 3 で示し たよらに約 $5 \times 10^{3} \mathrm{kA} / \mathrm{m}^{2}$ の磁界勾配が作用し，本実験 で調製した金属鉄粒子には約 $100 \mathrm{~g}$ (g は重力加速度) が 作用しているのに等しいと考えられる。この二層分離し た上層を除去すると黒色の下層は，作用させた磁界強度 に対して安定な水べース磁性流体と考えられる。

空気の入った密閉容器に水べース磁性流体を保存した 場合の，磁性流体内に分散している金属鉄粒子の館和磁 化の時間依存性を Fig. 8 に示す. 4 週間の経過まで飽和 磁化は低下し，それ以上経過しても粒子の飽和磁化は約 $0.8 \mathrm{~T}$ で一定となり，分散している金属鉄粒子の酸化は 示された期間ではこれ以上進行しなかった。

Fig. 9 には Fig. 3 で示した磁界分布に対して安定であ

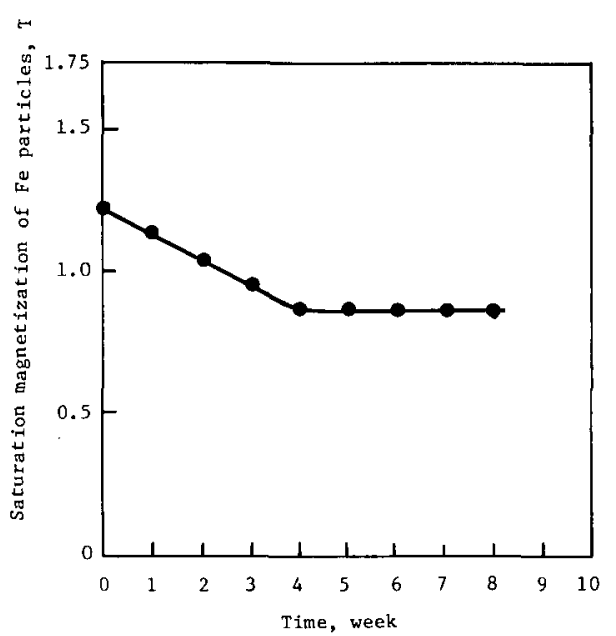

Fig. 8 Variation of saturation magnetization of metallic iron particles in the magnetic fluid $\left(\mathrm{Fe} 180 \mathrm{~kg} / \mathrm{m}^{3}\right)$ with time. 


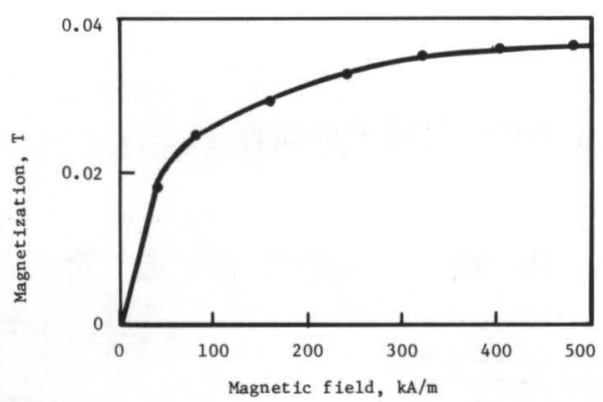

Fig. 9 Magnetization curve of water based magnetic fluid dispersing $220 \mathrm{~kg} / \mathrm{m}^{3}$ of metallic iron particles.

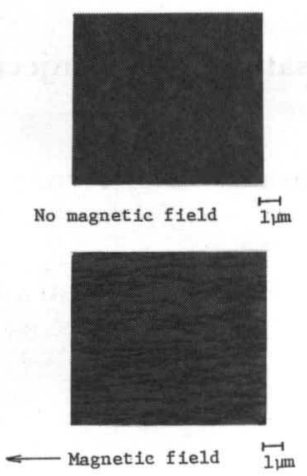

Photo. 1 Thin film of water based magnetic fluid dispersing metallic iron.

る磁性流体の磁化曲線の一例を示す，金属鉄粒子を 220 $\mathrm{kg} / \mathrm{m}^{3}$ 含有した磁性流体の飽和磁化は $0.036 \mathrm{~T}$ であった. $10 \mathrm{~nm}$ の粒径で飽和磁化が $0.35 \mathrm{~T}^{10)}$ であるマグネタイト を分散させた場合と比較して同じ固体濃度で 2 倍以上の 高い飽和磁化を示した.

Photo. 1 は，金属鉄粒子を分散させた水べース磁性流 体を $2 \mu \mathrm{m}$ の薄膜としてこれに磁界を作用させた場合と 作用させない場合を光学顕微鏡で観察した写真である. 磁界が作用しない場合は，金属鉄粒子が集合体を形成し て良好に分散している.一方, 磁界を作用させると, (写 真は $280 \mathrm{kA} / \mathrm{m}$ の磁界強度を作用させた場合である）粒 子はクラスターを磁界方向に形成した。 よって, 磁界を 作用させると磁性流体の粘度はクラスターのために変化 することが予測される. 磁性流体の粘度が磁性流体の流 動方向と平行でより粘度が増大寸ることは早くから報
告11)されている. Fig. 9 で示した磁化曲線の水べース磁 性流体を二重円筒型回転粘度計に入れ, 円筒と垂直に $280 \mathrm{kA} / \mathrm{m}$ の磁界を作用させると粘度は $1.6 \mathrm{~Pa} \cdot \mathrm{s}$ に上昇 し, 磁界を取り去ると再びるとの $0.9 \mathrm{~Pa} \cdot \mathrm{s}$ に回復した。

\section{$\mathrm{V}$ 結 言}

オレイン酸イオンを含む水素化ホウ素ナトリウム水溶 液に第一鉄イオンを添加して得られたオレイン酸イオン を被覆した金属鉄粒子を水中に SDBS 濃度およびTMA hydroxide 濃度を調整することにより安定に分散させる ことができた、金属鉄粒子表面のみかけの吸着層の厚さ は約 $10 \mathrm{~nm}$ と粘度測定から推定された. この懸濁液を 磁界分布中に長時間静置すると, 二層分離を生じるが, 分離した下部の液体は作用させた磁界分布に対して安定 な水べース磁性流体となった，分散している金属鉄粒子 は, 時間の経過とともに酸化を受けるが, 長時間経過後, 飽和磁化は約 $0.8 \mathrm{~T}$ と一定值を示した. また, 磁界を作 用させることにより磁性流体は磁界方向にクラスターを 生じ磁性流体の粘度は 2 倍程度に増加した.

$$
\text { 謝辞 }
$$

本研究を行らにあたり御教示頂いた東北大学中塚勝人 教授に感謝の意を表する.

\section{文献}

1) I. Nakatani and T. Furubayashi: J. Magn. Magn. Mat., 85 (1990), 11 ; 中谷, 土方, 小澤 : 磁性流体連合講演会磁性流 体講演論文集, 1, (1991), 28.

2) J. Shimoiizaka, K. Nakatsuka, T. Fujita and A. Kounosu: Proc. Int. Symp. Fine Particle Processing, 2 (1980), 1310.

3) R. Massart: IEEE Trans. Mag., MAG-17 (1981), 1247.

4）藤田, B. Jeyadevan, 真宮 : 粉体拈よび粉末治金, 36 (1989), 778.

5) R. E. Rosensweig, J. W. Nestor and R. S. Timmins: A. I. Ch. E. -I. Chem. E. Symposium Series, 5 (1965), 104.

6）中塚 : 資源・素材学会誌, 105 (1989), 67.

7) A. Watanabe, T. Uehori, S. Saito and Y. Imaoko: IEEE Trans. Mag., MAG-17 (1981), 1455.

8）藤田, 中塚, 下飯坂 : 日本鉱業会誌, 99 (1983), 387.

9) J. C. Bacri, R. Perzynski and D. Salin: J. Magn. Magn. Mat., 85 (1990), 27.

10) T. Sato, T. Iijima, M. Seki and N. Inagaki: J. Magn. Magn. Mat., 65 (1987), 252.

11) J. P. McTague: J. Chemical Phys., 51 (1969), 133. 